\title{
Sensory characteristics of Musculus longissimus thoracis et lumborum of bovine Nelore adult matured
}

\author{
Juliana Santos FARIAS ${ }^{1 \star}$, Francisco de Assis Fonseca de MACEDO ${ }^{1}$, Gladston Rafael de Arruda SANTOS ${ }^{1}$, \\ Leandro Teixeira BARBOSA ${ }^{1}$, Ludmila Couto GOMES ${ }^{1}$, Ana Andréia Teixeira BARBOSA ${ }^{2}$, \\ Ana Guerreiro KECHUANA ${ }^{3}$, Natalia Holtz Alves Pedrosa MORA ${ }^{4}$
}

\begin{abstract}
The goal of this paper was to perform the sensory evaluation of strip loin from adult Nelore cattle on the acceptance perspective of the consumer from Aracaju and purchase intention faged beef in different cutting thicknesses. Musculus longissimus thoracis and lumborum were used in three treatments with zero aging time with cutting thickness of $2.5 \mathrm{~cm} ; 21$ days aging with cutting thickness of $2.5 \mathrm{~cm}$; and 21 days aging withcutting thickness of $7.5 \mathrm{~cm}$. Eighty random consumers were invited to the sensory evaluationina local supermarket chain. The experimental design was completely randomized with three treatments and eight repetitions. The odour parameter did not differ $(\mathrm{P}>0.05)$ between treatments. There was a difference $(\mathrm{P}<0.004)$ between treatments regarding to flavour. The tenderness and the overall acceptance of the aged samples were higher $(\mathrm{P}<0.001)$ to non-aged samples with no difference $(\mathrm{P}>0.05)$ relative to the thickness. $85 \%$ of consumers from the city of Aracaju, based on the assigned scores, elected Musculus longissimus thoracis and lumborum from adult Nelore aged for 21 days a very attractive meat and demonstrated a positive purchase intention, regardless of the cutting thickness.
\end{abstract}

Keywords: acceptance; aging; consumers; tenderness; striploin.

Practical Application: Production of healthy meat and quality by means of practical and non-invasive techniques.

\section{Introduction}

The Brazilian herd consists of more than $80 \%$ of zebu breeds (Bos taurus indicus), and a highlight among these, the Nelore cattle, represents about $90 \%$ of this amount (Rubensam \& Monteiro, 2000; Bianchini et al., 2007; Associação Brasileira das Indústrias Exportadoras de Carnes, 2015). Over 85\% of beef cattle produced in Brazilare destined for the domestic market, with high consumption per capita of about $57 \mathrm{~kg} /$ year (Associação Brasileira das Indústrias Exportadoras de Carnes, 2015; Associação Brasileira de Proteína Animal, 2015).

The zebu cattle produce less tender meat and this is related to the slaughtering at later age, the higher level of calpastatin, the highest proportion of collagen in muscles and less deposition of intramuscular fat. The tenderness of the meat can be defined as the allowed chewing it. It is the main parameter used by consumers to value the meat product, being correlated to overall acceptance (Iocca et al., 2010; Lima et al., 2011).

The aging process appears as an effective alternative to improve the meat of old zebu cattle, consisting of a prolonged action of naturally occurring proteases in meat under refrigeration for a period ranging between 7 to 28 days, leading to the rupture of filaments and, consequently, softening the meat without

the need of mechanical strength and/or chemical additives (Koohmaraie, 1989; Krinchev et al., 2013). Aging exacerbates the sensory characteristics of meat, such as flavour, odour and especially tenderness, resulting in a product of better quality and greater acceptance by consumers, adding differentiated value to the product.

Knowing the preferences of the meat consumer is strategically critical to the production chain due to the cultural and/or ethnic diversity among the regions of the country.

Sañudo \& Campo (2008) describe the objectives of a sensory evaluation with consumers: the valuation of the potential market of a product; the study of the product quality; the knowledge of the acceptance of a new product on the market; the identification of important factors affecting consumer perceptions and the optimization of sale conditions of a product.

In the literature, the use of several anatomical sections in the study of maturation is remarkable. However, the thickness of the commercial cuts is deficient in information. Musculus longissimus thoracis et lumborum can be obtained from the market with two thickness packages. The cut close to $7.5 \mathrm{~cm}$ is found 
more frequently, followed by the thicknesses close to $2.5 \mathrm{~cm}$. In Brazilian cooking the Longissimus cooking for consumption is in cuts close to $2.5 \mathrm{~cm}$, penalizing the cuts with greater thickness, which need to be reduced. There is no scientific data guiding the ideal cutting thickness for the maturation process.

The objective of this work was to evaluate the sensorial characteristics of Musculus longissimus thoracis and lumborum of adult Nellore cattle matured with two cut thicknesses.

\section{Materials and methods}

24 half carcases of adult Nelore cattle with 6-8 teeth and average weight of $342 \mathrm{~kg}$ were selected at Frigorífico Nutrial Ltda., Under Federal Inspection (SIF 3246/SE) with slaughtering operation as recommended by RIISPOA (Brasil, 1952). The castrated steers were purchased by Nutrial in a single property of the region, which used as a termination the extensive system, in pasture brachiaria (Brachiaria brizantha). Musculus longissimus thoracis et lumborum were sampled in the boning between the first and sixth lumbar vertebrae. The sections with $2.5 \mathrm{~cm}$ or $7.5 \mathrm{~cm}$ length thickness were individuallyindividually vacuum packed, properly identified, and transported to the Meat Research Laboratory at the Federal University of Sergipe, where agingprocesses were held.

The meat was aged under controlled temperature of $0{ }^{\circ} \mathrm{C}$ to $2{ }^{\circ} \mathrm{C}$ using thermohygrometer coupled to refrigerators, and treatments were: zero aging time with cutting thickness of $2.5 \mathrm{~cm}(\mathrm{~A} 0 \mathrm{dC} 2.5 \mathrm{~cm}) ; 21$ days aging with cutting thickness of $2.5 \mathrm{~cm}(\mathrm{~A} 21 \mathrm{dC} 2.5 \mathrm{~cm})$; and 21 days aging with cutting thickness of $7.5 \mathrm{~cm}(\mathrm{~A} 21 \mathrm{dC} 7.5 \mathrm{~cm})$ with eight replications.

To perform the sensory evaluation the project was submitted to the Research Ethics Committee involving human beings as part of the requirements for carrying out the research, granting authorization (53995615.0.0000.5546). Samples of Musculus longissimus thoracis and lumborum with cutting thickness of $7.5 \mathrm{~cm}$ were divided into steaks of $2.5 \mathrm{~cm}$, steaks, weighed and identified, following the methodology proposed by Sañudo \& Campo (2008). No type of condiment was added to the meat to avoid influencing the treatments (Madruga et al., 2000). The samples were wrapped in foil and placed on a grill (model Gr0103b) after the temperature reached $170^{\circ} \mathrm{C}$. After the geometric center of the samples reached the internal temperature of $70^{\circ} \mathrm{C}$, measured by means of a digital spit thermometer, samples were immediately removed, each steak being divided into 10 uniform cubes $\left(2 \times 2 \mathrm{~cm}^{2}\right)$, encoded by treatment and stored appropriately in aluminium trays and covered with aluminium foil to prevent loss of volatiles and maintained in oven at $55^{\circ} \mathrm{C}$ until ready to be offered to the consumers. There were selected 80 random consumers ( 1 steak $\times 10$ cubes / steak $\times 8$ replicates) with the habit of eating beef. Consumers were approached by a properly trained staff with clear and succinct presentation of research, inviting them to attend the evaluation.

Each candidate consumed a sample of each treatment, a total of three samples proved, interspersed with water cracker and mineral water to clean the residue and to prevent interference between the samples.
The city of Aracaju has about 587,701 inhabitants (Instituto Brasileiro de Geografia e Estatística, 2010). Consumer groups that were selected corresponded to a category that had discernment to judge the product, adapted from the classification prepared by the Population Census (Instituto Brasileiro de Geografia e Estatística, 2010). Eighty participants were classified according to gender (female: $50 \%$; male: $50 \%$ ), age (20 to 29 years: $33.75 \%$; 30 to 39 years: $27.50 \%$; 40 to 49 years: $22.50 \%$; 50 to 59 years: $11.25 \% ; 60$ to 69 years: $5.00 \%$ ) and education degree (elementary school: $2.50 \%$; high school: $40.00 \%$; higher education: $57.50 \%$ ).

The evaluation was performed in a large supermarket chain that sells aged beef, with large flow of people to compose the population sample and also meet the recommendations outlined by Cañeque \& Sañudo (2005) as the necessary infrastructure to the experiment.

For the product evaluation it was made an affective acceptance test, in which 80 beef consumers (not trained) were divided into eight sessions of 10 people and they all assigned grades for the three treatments. In the end, they responded as the intention to purchase through closed question with "yes" or "no" (Azevedo et al., 2011).

All consumers were instructed regarding the test procedure and to fill the answer form before starting the evaluation. It was used hedonic scale from 1 to 9 (1-dislike extremely; 2-dislike very much; 3-dislike moderately; 4-dislike slightly; 5-Neither like nor dislike; 6-like slightly; 7-like moderately; 8-like very much; 9- like extremely) adapted from American Meat Science Association (1995), to assess the tenderness (hardness sense during chewing), odour intensity (amplitude of beef characteristic aroma), flavour intensity (amplitude of beef characteristic flavour sense during chewing) and overall acceptance (overall acceptability of the aged meat product).

The differences between the averages of the sensory characteristics and clusters were performed using SPSS v15.0 Statistical Program (IBM SPSS Statistics, SPSS Inc., Chicago. USA) through a comparison of means using a GLM (general linear model), in which treatments were considered fixed effects and the consumer was consideredrandom effect, comparing the variances by the Duncan test at the significance level of $5 \%$.

The cluster analyses were performed to determine the different groups of consumers, to define the overall acceptability and the meat tenderness. It was used the XLSTAT (v.7.5.3), which is a complement to the EXCEL program. It was also carried out aprincipal component analysis to identify the relationships between treatments and attributes evaluated in the meat. Correlations between attributes were assessed using Pearson's correlation coefficient.

Microbiological testing was performed by microdrop technology described by Romeiro (2001) for psychotropic $\left(2.18 \times 10^{5} \mathrm{CFU} / \mathrm{g}\right)$ and mesophiles count $\left(2.4 \times 10^{5} \mathrm{CFU} / \mathrm{g}\right)$. These were found below critical level $\left(10^{6} \mathrm{CFU} / \mathrm{g}\right)$, indicating that the samples were suitable for consumption. 


\section{Results and discussion}

The analysis of variance for grades attributed by consumers in the sensory evaluation is shown in Table 1 . The aging periods and the cutting thicknesses evaluated did not influence the odour intensity $(\mathrm{P}>0.05)$. Nevertheless, other parameters were affected by the treatments.

For the parameters intensity of flavor, softness and overall acceptance, the treatments showed differences between the non - mature meats $(\mathrm{A} 0 \mathrm{dC} 2.5 \mathrm{~cm})$ and maturity at 21 days $(\mathrm{A} 21 \mathrm{dC} 2.5 \mathrm{~cm}$ and $\mathrm{A} 21 \mathrm{dC} 2.5 \mathrm{~cm})$. It can be said that regardless of the thickness of the cut, maturation improves the flavor of the meat, without, however, altering the characteristic flavor of the species, based on the grades attributed by the consumers.

The softness of meat is the main parameter used by consumers to value it. The resulting, significantly superior and satisfactory notes for mature meats explain the expected behavior. Since the maturation process improves the organoleptic characteristics, enhancing the tenderness, flavor and odor of the meat, which are associated with the overall acceptance of the product.

This result supports the hypothesis that Nelore beef has higher hardness due to the increased presence of calpastatin, which inhibit the enzymatic activity of calpain, responsible for about $90 \%$ of the meat softening (Manço et al., 2006; Abrahão, 2007). Thus, according to Bianchini et al. (2007), Nelore beef requires a minimum of 7 days of aging to become tender.

Similar results were found by Brito (2013) in which the means for meat tenderness, flavour and overall acceptability were around $6.71 ; 7.25$ and 7.01, respectively, indicating that the participants liked the meat moderately. Fernandes et al. (2009) obtained lower values than those obtained in this study regarding overall acceptance for Nelore aged beef (6.80) and considered the meat well accepted.

According to principal component analysis (Figure 1), the total variation is explained between the two axes and the attributes of odour, tenderness, flavour and overall acceptance are in the right side of the F1-axis, located near the aged treatments, either 2.5 or $7.5 \mathrm{~cm}$ in thickness. The non-aged treatment is located on the left side of the F1-axis and it is inversely correlated with the acceptance attributes.

It is remarkable the emphasis for the aged beef given by the consumers, confirmed by the scores attributed to the overall acceptance in the sensory evaluation (Figure 1). The analyses displayed in Table 2 showed high correlation between all the characteristics evaluated by consumers. Through Pearson correlations it was observed that the odour $(r=0.99)$ and flavour intensity parameters $(r=0.98)$ and tenderness $(r=0.97)$ are highly correlated with the meat overall acceptance, demonstrating the relevance of the use of these variables in the sensory evaluation methodology with consumers.

Regarding purchase intention, questioned to the participants of the sensory evaluation, $98.75 \%$ of consumers answered positively to proven samples in the sensory evaluation. The participants chose the beef aged for 21 days, regardless of the cutting thickness, as the most attractive, with purchase intention of $85 \%$ (A0dC2.5 $\mathrm{cm}=15 \%$; A $21 \mathrm{dC} 2.5 \mathrm{~cm}=42.5 \%$ and $\mathrm{A} 21 \mathrm{dC} 7.5 \mathrm{~cm}=42.5 \%$ ), confirming the importance of this methodology.

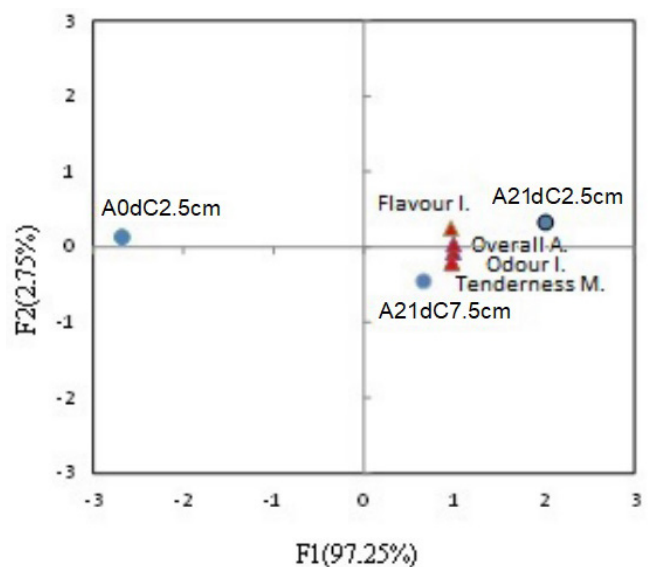

Figure 1. Principal component analysis of the quality parameters and sensory attributes for treatments regarding cutting thicknesses and aging time: A0dC2.5cm (zero aging time with cutting thickness of $2.5 \mathrm{~cm}$ ); A21dC2.5cm (21 days of aging with cutting thickness of $2.5 \mathrm{~cm}$ ); A21dC7.5cm (21 days of aging with cutting thickness of $7.5 \mathrm{~cm}$ ).

Table 1. Means and standard deviations for the sensory characteristics of Nelore beef aged for zero and 21 days, with cutting thickness of 2.5 and $7.5 \mathrm{~cm}$ ( $\mathrm{n}=80$ consumers).

\begin{tabular}{ccccc}
\hline & A0dC2.5cm & A21dC2.5cm & A21dC7.5cm & P-value \\
\hline Odour intensity & $6 \mathrm{a} \pm 2$ & $6 \mathrm{a} \pm 2$ & $6 \mathrm{a} \pm 2$ & 0.805 \\
Flavour intensity & $6 \mathrm{~b} \pm 2$ & $7 \mathrm{a} \pm 2$ & $7 \mathrm{a} \pm 2$ & 0.004 \\
Meat tenderness & $6 \mathrm{~b} \pm 2$ & $7 \mathrm{a} \pm 2$ & $7 \mathrm{a} \pm 2$ & $<0.001$ \\
Overall acceptability & $6 \mathrm{~b} \pm 2$ & $7 \mathrm{a} \pm 2$ & $7 \mathrm{a} \pm 2$ & 0.001 \\
\hline
\end{tabular}

Means followed by different letters differ at $5 \%$ probability. Based on a 9-point scale (1 - dislike extremely; to 9 - like extremely).

Table 2. Correlation between the sensory attributes evaluated.

\begin{tabular}{ccccc}
\hline & Odour intensity & Tenderness & Flavour intensity & Overall acceptability \\
\hline Odour intensity & 1 & 0.990 & 0.950 & 0.995 \\
Tenderness & & 1 & 0.897 & 0.970 \\
Flavour intensity & & & 1 & 0.977 \\
Overall acceptability & & & & 1 \\
\hline
\end{tabular}


Knowing consumer preferences for a specific food is essential. Studies evaluating meat acceptability have shown different behaviours between different consumer groups, which represent various segments of the beef market, producing variations in demand. This is due to the differences in perception, familiarity and behaviors learned, memorized and recognized by the lived experience, or even a combination of these aspects, translating the eating habits of each one (Murray et al., 2001).

Considering the socio-demographic profile of the participant population from Aracaju, the cluster analysis allowed to classify consumers into groups with similar criteria for tenderness (Table 3 ) and overall acceptance (Table 4), discussed respectively in Tables 5 and 6 . Nonetheless, these groups are not homogeneous regarding to academic level, age or gender.

About the tenderness acceptability, clusters analysis presented in Table 5 show differences between treatments $(\mathrm{P}<0.05)$. In cluster 1 , non-aged meat with cutting thickness of $2.5 \mathrm{~cm}(\mathrm{~A} 0 \mathrm{dC} 2.5 \mathrm{~cm})$ were similar to the 21 days of aging (A21dC2.5 cm), receiving the highest scores. Meanwhile, mature meats with $7.5 \mathrm{~cm}$ thickness differed $(\mathrm{P}<0.001)$ from samples with a $2.5 \mathrm{~cm}$ cut thickness, receiving a lower grade. For this group of consumers it was noticed the preference for the meats of smaller thickness of cut.

Through the clusters 2 and 3 was possible to see the effect of sex on the measured variables. In cluster 2 , the aged beef with $2.5 \mathrm{~cm}$ differed from the non-aged of equal thickness $(\mathrm{P}<0.001)$. However, the non-aged samples with $2.5 \mathrm{~cm}$ behaved similarly to the aged meat with cutting thickness of $7.5 \mathrm{~cm}$. Cluster 2 is represented by $75 \%$ of the male population and showed significant differences in the treatments $(\mathrm{P}<0.001)$ for the aging period, resulting in a marked preference for the aged sample with cutting thickness of $2.5 \mathrm{~cm}(\mathrm{~A} 21 \mathrm{dC} 2.5 \mathrm{~cm})$.

In cluster 3 , the treatment of zero aging time with cutting thickness of $2.5 \mathrm{~cm}$ differ $(\mathrm{P}<0.001)$ of the aged beef $(\mathrm{A} 21 \mathrm{dC} 2.5 \mathrm{~cm}$ and $\mathrm{A} 21 \mathrm{dC} 7.5 \mathrm{~cm})$, regardless of cutting thickness. This cluster is represented by $64.7 \%$ of the female population and it is the population group with predominance of the intermediate level of education (52.9\%) and aged from 30 to 39 years (47.1\%). However, this group showed preference to the aged samples, independent of the cutting thickness.

The cluster 4, composed of the minor percentage of the population (11.25\%), attributed the lowest scores for tenderness acceptability, with negative purchase intention of $11.1 \%$ (Table 3 ). There was a rejection of aged samples with cutting thickness of
$2.5 \mathrm{~cm}(\mathrm{P}<0.001)$, but the cluster 4 was favourable to the meat aged for 21 days with cutting thickness of $7.5 \mathrm{~cm}$.

The broadest group between categories, with uniform gender distribution and predominant higher education level (50\%), which are represented in cluster 5, scored the treatments with the highest grades. It is believed that individuals with higher

Table 3. Description of the population of the Tenderness clusters.

\begin{tabular}{|c|c|c|c|c|c|}
\hline Cluster & 1 & 2 & 3 & 4 & 5 \\
\hline Sex & $(\%)$ & $(\%)$ & $(\%)$ & $(\%)$ & $(\%)$ \\
\hline Female & 50.0 & 25.0 & 64.7 & 55.6 & 50.0 \\
\hline Male & 50.0 & 75.0 & 35.3 & 44.4 & 50.0 \\
\hline Age & $(\%)$ & (\%) & $(\%)$ & (\%) & (\%) \\
\hline $20-29$ & 30.0 & 50.0 & 35.3 & 22.2 & 31.3 \\
\hline $30-39$ & 10.0 & 16.7 & 47.1 & 33.3 & 25.0 \\
\hline $40-49$ & 40.0 & 16.7 & 11.8 & 33.3 & 21.9 \\
\hline $50-59$ & 20.0 & 16.7 & 5.9 & 11.1 & 12.5 \\
\hline $60-69$ & & & & & 9.4 \\
\hline Academic Level & $(\%)$ & (\%) & $(\%)$ & (\%) & (\%) \\
\hline Elementary School & & & & & 6.3 \\
\hline High School & 30.0 & 33.3 & 52.9 & 22.2 & 43.8 \\
\hline Higher education & 70.0 & 66.7 & 47.1 & 77.8 & 50.0 \\
\hline Purchase intention & (\%) & $(\%)$ & $(\%)$ & (\%) & (\%) \\
\hline Yes & 100.0 & 100.0 & 100.0 & 88.9 & 100.0 \\
\hline No & & & & 11.1 & \\
\hline
\end{tabular}

Table 4. Population data for theoverall acceptance cluster.

\begin{tabular}{|c|c|c|c|c|}
\hline Cluster & 1 & 2 & 3 & 4 \\
\hline Sex & $(\%)$ & $(\%)$ & $(\%)$ & (\%) \\
\hline Female & 25.0 & 38.5 & 55.0 & 60.0 \\
\hline Male & 75.0 & 61.5 & 45.0 & 40.0 \\
\hline Age & $(\%)$ & $(\%)$ & $(\%)$ & (\%) \\
\hline $20-29$ & & 23.1 & 50.0 & 36.7 \\
\hline $30-39$ & 50.0 & 30.8 & 25.0 & 23.3 \\
\hline $40-49$ & 50.0 & 30.8 & 10.0 & 20.0 \\
\hline $50-59$ & & 11.5 & 10.0 & 13.3 \\
\hline $60-69$ & & 03.8 & 05.0 & 06.7 \\
\hline Academic Level & $(\%)$ & $(\%)$ & $(\%)$ & (\%) \\
\hline Elementary School & & 03.8 & & 03.3 \\
\hline High School & & 34.6 & 45.0 & 46.7 \\
\hline Higher education & 100.0 & 61.5 & 55.0 & 50.0 \\
\hline Purchase intention & $(\%)$ & $(\%)$ & $(\%)$ & (\%) \\
\hline Yes & 75.0 & 100.0 & 100.0 & 100.0 \\
\hline No & 25.0 & & & \\
\hline
\end{tabular}

Table 5. Means and standard deviations for the acceptability of five groups of consumers, identified by cluster analysis for Tenderness ( $\mathrm{n}=80$ consumers).

\begin{tabular}{|c|c|c|c|c|c|c|}
\hline & $\mathrm{n}$ & $\%$ & $\mathrm{~A} 0 \mathrm{dC} 2.5 \mathrm{~cm}$ & $\mathrm{~A} 21 \mathrm{dC} 2.5 \mathrm{~cm}$ & $\mathrm{~A} 21 \mathrm{dC} 7.5 \mathrm{~cm}$ & P-value \\
\hline Cluster 1 & 10 & 12.50 & $7 \mathrm{a} \pm 1$ & $8 \mathrm{a} \pm 1$ & $4 \mathrm{~b} \pm 2$ & $<0.001$ \\
\hline Cluster 2 & 12 & 15.00 & $3 b \pm 1$ & $8 \mathrm{a} \pm 2$ & $5 b \pm 2$ & $<0.001$ \\
\hline Cluster 3 & 17 & 21.25 & $4 \mathrm{~b} \pm 1$ & $8 \mathrm{a} \pm 1$ & $8 \mathrm{a} \pm 1$ & $<0.001$ \\
\hline Cluster 4 & 9 & 11.25 & $5 b \pm 3$ & $3 c \pm 1$ & $6 \mathrm{a} \pm 2$ & 0.005 \\
\hline Cluster 5 & 32 & 40.00 & $8 \mathrm{~b} \pm 1$ & $8 b \pm 2$ & $9 \mathrm{a} \pm 1$ & 0.043 \\
\hline
\end{tabular}

Different letters in the same line differ at $5 \%$ probability. Based on a 9-point scale (1 - dislike extremely; to 9 - like extremely). 
Table 6. Means and standard deviations of four consumer groups identified by cluster analysis for Overall Acceptance ( $\mathrm{n}=80$ consumers).

\begin{tabular}{lcccccc}
\hline & $\mathrm{n}$ & $\%$ & A0dC2.5cm & A21dC2.5cm & A21dC7.5cm & P-value \\
\hline Cluster 1 & 04 & 05.00 & $4 \mathrm{a} \pm 2$ & $4 \mathrm{a} \pm 2$ & $3 \mathrm{~b} \pm 1$ & 6.016 \\
Cluster 2 & 26 & 32.50 & $7 \mathrm{a} \pm 1$ & $7 \mathrm{a} \pm 2$ & $6 \mathrm{~b} \pm 2$ & 8.217 \\
Cluster 3 & 20 & 25.00 & $4 \mathrm{~b} \pm 1$ & $8 \mathrm{a} \pm 1$ & $8 \mathrm{a} \pm 1$ \\
Cluster 4 & 30 & 37.50 & $8 \mathrm{~b} \pm 1$ & $8 \mathrm{~b} \pm 1$ & $9 \mathrm{a} \pm 1$ & 0.000 \\
\hline
\end{tabular}

Different letters in the same line differ at $5 \%$ probability. Based on a 9-point scale ( 1 - dislike extremely; to 9 - like extremely).

levels of education have more knowledge and requirements about the quality on the items consumed.

The Musculus longissimus thoracis and lumborum with a thickness of $7.5 \mathrm{~cm}$ and 21 days of maturation presented the highest acceptability of softness in relation to meat with $2.5 \mathrm{~cm}$ cut thickness, matured or not, according to $40 \%$ of participants of cluster 5 .

Beef with cutting thickness of $7.5 \mathrm{~cm}$ and aged for 21 days, probably due to its higher muscle area, may have concentrated further enzymatic action in the natural process of meat softening, making the Musculus longissimus thoracis and lumborum with $7.5 \mathrm{~cm}$ thickness as good or more pleasing to consumers comparing to the cutting thickness of $2.5 \mathrm{~cm}$. Therefore, it can be concluded that both available commercial cuts in the supermarket satisfy beef consumers.

The cluster analysis of overall acceptance is shown in Table 4 and the results discussed in Table 6, according to the applied treatments.

The cluster 1 of global acceptance, represented mostly by the male sex (75\%), presented a negative purchase response of $25 \%$, however, it represents only $5 \%$ of the participants, being between 30 and 49 years of age. This minority group scored the lowest treatments for global acceptance of the meat, differing between treatments maturing for 21 days with thicknesses of $2.5(\mathrm{~A} 21 \mathrm{dC} 2.5 \mathrm{~cm})$ and $7.5 \mathrm{~cm}(\mathrm{~A} 21 \mathrm{dC} 7.5 \mathrm{~cm})$, in relation to the thickness $(\mathrm{P}<0.05)$, presenting similar notes for the treatment without maturation $(\mathrm{A} 0 \mathrm{dC} 2.5 \mathrm{~cm})$. According to Cain \& Stevens (1989) the process of human aging is characterized by a decline in smell and taste sensitivity. In addition, older consumers have different perceptions of texture, probably related to physiological factors such as difficulty in chewing and swallowing, teething state, coordination and tenderness of the oral cavity (Peleg, 1993).

Just as cluster 2, with a very broad representation, presents a greater difference in relation to gender (Table 4), showing that there is sex interference in consumer preference. Males make up the largest cluster 2 cluster with $61.5 \%$, the group of 30 to 39 and 40 to 49 years old is the most representative (30.8\%, both) of the group, and with a higher level of education higher than (61.5\%). Representing $32.5 \%$ of the participants, there was a significant difference $(\mathrm{P}<0.05)$ between the cut thicknesses of the meats (Table 6). Regarding the grades, the evaluated samples received higher marks for global acceptance, varying between the "I liked slightly" and "I liked very much" rankings, indicating consumer satisfaction.

Cluster 3, represented by the female audience with $55 \%$, in the 20 to 29 age group (50\%) and higher education (55\%), corresponds to $25 \%$ of the participants. This group presented difference as a function of the maturation period $(\mathrm{P}<0.05)$. For the non-mature meats $(\mathrm{A} 0 \mathrm{dC} 2.5 \mathrm{~cm})$, lower grades were obtained (A21dC2.5 $\mathrm{cm}$ and $\mathrm{A} 21 \mathrm{dC} 7.5 \mathrm{~cm}$ ), demonstrating the beneficial effect of maturation on global acceptance.

The preference of meat cuts in consumption may also be related to sex by the condition and ease of preparation, as well as the frequency of purchase of the product in the home and by who prepares it (Murray et al., 2001). By means of the cluster analyzes and the score, it was possible to observe the consumers preference for samples matured for 21 days, not interfering with the commercialized cut thickness, either in a piece with a larger muscular volume $(7.5 \mathrm{~cm})$ or as steaks $(2.5 \mathrm{~cm})$, regardless of gender, age group or educational level of the participating population.

Through the cluster analysis and the score it was observed consumer preference for samples aged for 21 days, not suffering interference regarding the cutting thickness, either pieces of greater muscle size $(7.5 \mathrm{~cm})$ or as steaks $(2.5 \mathrm{~cm})$, regardless of gender, age or educational level of the participant population. On the other hand cluster 4 has the greatest representation of participants $(37.5 \%)$ with women predominance $(60 \%)$ and ranging from 20 to 29 years (36.7\%). It is the group that assigned the top grades in all treatments for overall acceptability, without report differences between treatments.

With reference to the classification by hedonic scale, the scores assigned to the samples were positive, with an average classified as acceptable to very good for the evaluated parameters. One possible reason for some low grades presented is due to the fact that the absence of salt and/or condiments on the product for consumption, which may have influenced the consumers with preference to season foods.

\section{Conclusion}

The Musculus longissimus thoracis et lumborum of adult Nellore steers can be matured with a cut thickness of $2.5 \mathrm{~cm}$ or $7.5 \mathrm{~cm}$. Musculus longissimus thoracis et lumborum maturation of adult Nellore steers for 21 days is recommended because it was an attractive meat with good acceptability and a positive intention to buy.

\section{References}

Abrahão, A. R. (2007). Análise de algumas proteinas miofibrilares envolvidas na maciez da carne em bovinos de corte (Tese de doutorado). Universidade Estadual Paulista, Botucatu.

American Meat Science Association - AMSA. (1995). Research guidelines for cookery, sensory and instrumental tenderness measurement of fresh meat (pp. 47-48). Chicago: AMSA. 
Associação Brasileira das Indústrias Exportadoras de Carnes - ABIEC. (2015). Pecuária: rebanho bovino brasileiro. São Paulo: ABIEC. Retrieved from http://www.abiec.com.br/3_rebanho.asp

Associação Brasileira de Proteína Animal - ABPA. (2015). Cenário carnes 2014/2015. Brasília: ABPA. Retrieved from http://www.agricultura. gov.br/arq_editor/file/camaras_setoriais/Aves_e_suinos/25RO/ Cen\%C3\%A1rio\%20Carnes\%202014\%202015.pdf

Azevedo, F. L. A. A., Silva, A. D. F., Maciel, J. F., Moreira, R. T., \& Farias, L. R. G. (2011). Avaliação sensorial de pão de forma elaborado com soro de leite em pó. Revista Brasileira de Produtos Agroindustriais, 13(1), 37-47. http://dx.doi.org/10.15871/1517-8595/rbpa.v13n1p37-47.

Bianchini, W., Silveira, A. C., Jorge, A. M., Arrigoni, M. D. B., Martins, C. L., Rodrigues, É., Hadlich, J. C., \& Andrighetto, C. (2007). Efeito do grupo genético sobre as características de carcaça e maciez da carne fresca e maturada de bovinos superprecoces. Revista Brasileira de Zootecnia, 36(6), 2109-2117. http://dx.doi.org/10.1590/S151635982007000900022 .

Brasil. Ministério da Agricultura. (1952). Regulamento da inspeção industrial e sanitária de produtos de origem animal. Brasília: Ministério da Agricultura.

Brito, G. F. (2013). Características de qualidade e aceitação sensorial da carne bovina de diferentes grupos genéticos terminados em confinamento (Dissertação de mestrado). Universidade Estadual Paulista, Jaboticabal.

Cain, W. S., \& Stevens, J. C. (1989). Uniformity of olfactory loss in ageing. Annals of the New York Academy of Sciences, 561(1), 29-38. http:// dx.doi.org/10.1111/j.1749-6632.1989.tb20967.x. PMid:2735685.

Cañeque, V., \& Sañudo, C. (2005). Estandarización de las metodologias para evaluar la calidade del producto (Serie Ganadera, No. 3). Madri: INIA.

Fernandes, A. R. M., Sampaio, A. A. M., Henrique, W., Oliveira, E. A., Oliveira, R. V., \& Leonel, F. R. (2009). Composição em ácidos graxos e qualidade da carne de tourinhos Nelore e Canchim alimentados com dietas à base de cana-de-açúcar e dois níveis de concentrado. Revista Brasileira de Zootecnia, 38(2), 328-337. http://dx.doi. org/10.1590/S1516-35982009000200016.

Instituto Brasileiro de Geografia e Estatística - IBGE. (2010). PPM 2010: rebanho bovino cresce 1,6\% e chega a 212,8 milhões de cabeças. Rio de Janeiro: IBGE. Retrieved from http://saladeimprensa.ibge. gov.br/noticias?view $=$ noticia\&id $=1 \&$ idnoticia $=2241 \&$ busca $=1 \& \mathrm{t}=\mathrm{p}$ pm-2011-rebanho-bovino-cresce-1-6-chega-212-8-milhoes-cabecas

Iocca, A. F. S., Catanozi, M. P. L. M., \& Lemos, A. L. S. C. (2010). Adição de plasma bovino em salmouras para injeção de coxão duro bovino (m. Bicepsfemoris) e seus efeitos no ph e na carga microbiana de bifes cozidos, embalados a vácuo e mantidos sob refrigeração. Revista Alimentos e Nutrição, 21(3), 443-452.

Koohmaraie, M. (1989). The role of endogenous proteases in meat tenderness. In Proceedings of the 41st Annual Reciprocal Meat Conference of the American Meat Science Association (pp. 89). Wyoming: University of Wyoming.

Krinchev, A. F. B., Bolfe, F. C., Pinto, A. B. R., Giangareli, B. L., Vero, J. G., Rogel, C. P., Fagan, P., \& Bridi, A. M. (2013). Avaliação microbiológica da carne maturada de novilhos Nelore e cruza Angus x Nelore. In Anais do XXIII Congresso Brasileiro de Zootecnia: Zootecnia do Futuro: Produção Animal Sustentável. Foz do Iguaçu: Universidade Estadual do Oeste do Paraná.

Lima, D. M. Jr., Rangel, A. H. N., Urbano, S. A., Maciel, M. V., \& Amaro, L. P. A. (2011). Alguns aspectos qualitativos da carne bovina. Revista Acta Veterinaria Brasilica, 5(4), 351-358.

Madruga, M. S., Arruda, S. G. B., Andrade, L. T., \& Beserra, F. J. (2000). Efeito da castração sobre parâmetros químicos, físico-químicos e sensoriais da carne caprina de animais mestiços. Revista Ciência e Tecnologia de Alimentos, 20(1), 23-26. http://dx.doi.org/10.1590/ S0101-20612000000100005.

Manço, M. C. W., Roça, R. O., Corrente, J. E., Ramiro, J., \& Abrahão, A. (2006). Características da carcaça e da carne de bovinos anelorados: ph, área de olho de lombo e composição centesimal. In M. C. W. Manço, Características físico-químicas, sensoriais e higiênicas da carne bovina em duas classes de maturidade e sob influência da maturação. Botucatu: Universidade Estadual Paulista.

Murray, J. M., Delahunty, C. M., \& Baxter, I. A. (2001). Descriptive sensory analysis: past, present and future. Food Research International, 34(6), 461-471. http://dx.doi.org/10.1016/S0963-9969(01)00070-9.

Peleg, M. (1993). Tailoring texture for the elderly: theoretical aspects and technological options. Critical Reviews in Food Science and Nutrition, 33(1), 45-55. http://dx.doi.org/10.1080/10408399309527611. PMid:8424854.

Romeiro, R. S. (2001). Métodos em bacteriologia de plantas. Viçosa: UFV.

Rubensam, J. M., \& Monteiro, E. M. (2000). Maciez e atividade de calpastatina em carne bovina (Documentos, No. 28). Bagé: EMBRAPA. Retrieved from https://www.embrapa.br/pecuaria-sul/ busca-de-publicacoes/-/publicacao/228286/maciez-e-atividade-decalpastatina-em-carne-bovina

Sañudo, C., \& Campo, M. M. (2008). Calidad de la carne de vacuno. In C. Sañudo, V. Jimeno \& M. Cerviño (Eds.), Producción de ganado vacuno de carne y tipos comerciales en España (1st ed., pp. 207-235). Madri: Schering-Ploug. 